\title{
Potassium Fluxes in Neocosmospora vasinfecta
}

\author{
By K. BUDD \\ Department of Biology, Queen's University, \\ Kingston, Ontario, Canada
}

(Received 17 March 1975)

\begin{abstract}
SUMMARY
The unidirectional $\mathrm{K}^{+}$fluxes across the mycelial surface of Neocosmospora vasinfecta were determined using ${ }^{42} \mathrm{~K}$. Influx was mediated by at least two kinetically distinct systems, one having an apparent $K_{m}$ of $6.5 \mu$-equiv. $\mathrm{K}^{+} / 1$ and the other of about $\mathrm{I} \cdot 0 \mathrm{~m}$-equiv. $\mathrm{K}+1$. The $V_{\max }$ for both systems was in the range $\mathrm{I} 8$ to $22 \mu$-equiv. $\mathrm{K}^{+} / \mathrm{I} 00 \mathrm{mg}$ mycelial dry matter/h $\left(\mathrm{I} \cdot 0\right.$ to $\mathrm{I} \cdot 2 \mathrm{~m}$-equiv. $\mathrm{K}^{+} / 1$ cell-water/min). Influx was strongly inhibited by 2,4-dinitrophenol, sodium azide, sodium arsenate and anaerobiosis. $\mathrm{K}^{+}$efflux was dependent on the external $\mathrm{K}^{+}$ concentration and ranged from 3 to $10 \%$ of mycelial $\mathrm{K}^{+} / \mathrm{h}$. The maximum efflux rate was always considerably less than the initial influx rate for the $\mathrm{K}^{+}$concentrations examined. During incubation in dilute $\mathrm{KCl}$ solutions, $\mathrm{K}^{+}$influx decreased to a value approaching the $\mathrm{K}^{+}$efflux rate. It is considered that equilibrium with external $\mathrm{K}^{+}$is attained primarily by the regulation of $\mathrm{K}^{+}$influx, and that this may be the principal mechanism controlling cytoplasmic $\mathrm{K}^{+}$levels.

Adsorption of $\mathrm{K}^{+}$was also observed throughout the $\mathrm{K}^{+}$concentration range examined and can be attributed to two distinct $\mathrm{K}^{+}$-binding entities at the mycelial surface, half-saturating at approximately $0.1 \mathrm{mM}$ - and $4.4 \mathrm{mM}-\mathrm{KCl}$ respectively.
\end{abstract}

\section{INTRODUCTION}

Among inorganic ions, potassium appears to have particularly high mobility across the surface membranes of many types of cell. Detailed investigations of $\mathrm{K}^{+}$fluxes in fungi have been confined to baker's yeast, Saccharomyces cerevisiae (e.g. Rothstein \& Brucc, 1958) and Neurospora crassa (e.g. Slayman \& Tatum, 1965). These studies indicated rather rapid unidirectional fluxes, and this was true in Neurospora even when the mycelium was in quasi-equilibrium with respect to the external potassium. In yeast, influx was comparable to that in Neurospora, and the approach to equilibrium with external potassium was characterized by increasing efflux, although modulation of influx was also sometimes seen (Rothstein \& Bruce, 1958).

In Neocosmospora (Budd, $\mathrm{I} 969 b$ ), $\mathrm{Rb}^{+}$ions had limited ability to remove $\mathrm{K}^{+}$ions from the mycelium, although $\mathbf{R b}^{+}$effectively inhibited $\mathrm{K}^{+}$uptake. It was considered that $\mathrm{K}^{+} / \mathrm{K}^{+}$exchange at the mycelial surface was unlikely to be the only factor involved in regulating the mycelial $\mathrm{K}^{+}$level, and it was suggested that much of the mycelial $\mathrm{K}^{+}$might not be available for exchange. The present studies with ${ }^{42} \mathbf{K}^{+}$show that the bulk of mycelial potassium exchanges only slowly with external potassium in Neocosmospora, and indicate that regulation of $\mathrm{K}^{+}$influx is a key factor in determining net uptake. In addition, some characteristics of potassium adsorption by the mycelium are described. 


\section{METHODS}

Neocosmospora vasinfecta ATCCII686 was purchased from the American Type Culture Collection and grown in liquid shaken culture at $25 \pm 0.5{ }^{\circ} \mathrm{C}$, using Medium Gi (Budd, $1969 a$ ). The mycelium was harvested while still in exponential growth, when the absorbance $(600 \mathrm{~nm}, \mathrm{I} \mathrm{cm}$ cell) of a tenfold dilution of the culture was 0.35 to 0.50 . The mycelium was separated from growth medium by filtration under reduced pressure, using Whatman No. 54 filter paper circles held in a Millipore filter, and thoroughly washed by resuspension in demineralized water. Replicate samples of 45 to $110 \mathrm{mg}$ dry wt were prepared by taking equal volumes of the well-stirred final suspension, filtering as above, and transferring to experimental solutions. Mycelial suspensions (0.08 to $0.15 \mathrm{mg}$ dry matter $/ \mathrm{ml}$ ) were incubated at 22 to $25^{\circ} \mathrm{C}$ and continually agitated by a stream of air, or, where anaerobiosis was required, oxygen-free $\mathrm{N}_{2}$ gas. For studies of influx or efflux, suspensions were placed in glass columns and periodically sampled via a wide-bore glass stopcock at the bottom of the column. The $\mathrm{pH}$ of the unbuffered suspensions was between 5.3 and $5 \cdot 8$, and preliminary experiments showed that $\mathrm{pH}$ shifts within this range had a negligible effect on influx rate.

For the determination of unidirectional $\mathrm{K}^{+}$fluxes, ${ }^{42} \mathrm{~K}$ was used. This was received from I.C.N., Irvine, California, U.S.A., as $\mathrm{K}_{2} \mathrm{CO}_{3}$ (approx. $10 \mathrm{mCi} / \mathrm{m}$-equiv. $\mathrm{K}^{+}$) or $\mathrm{KCl}$ (approx. $25 \mathrm{mCi} / \mathrm{m}$-equiv. $\mathrm{K}^{+}$) in aqueous solution, or from the McMaster University Nuclear Reactor, Hamilton, Ontario, Canada, as $\mathrm{K}_{2} \mathrm{CO}_{3}$ powder (4 to $10 \mathrm{mCi} / \mathrm{m}$-equiv. $\mathrm{K}^{+}$). The carbonates were neutralized with analytical grade $\mathrm{HCl}$. The isotope was presented to the mycelium as aqueous $\mathrm{KCl}\left(0 \cdot \mathrm{I}\right.$ to $\mathrm{I} \cdot 2 \mathrm{mCi} / \mathrm{m}$-equiv. $\left.\mathrm{K}^{+}\right)$. To estimate ${ }^{42} \mathrm{~K}^{+}$content, samples of mycelium were filtered free of radioactive media as described above and scraped from the filter paper with a stainless steel spatula. They were transferred to plastic vials and counted as soon as possible in a Nuclear Chicago model 4233 automatic gamma counting system. Simultaneously, a portion (IO or $25 \mu \mathrm{l}$ ) of the labelled $\mathrm{KCl}$ used in that particular experiment was counted, to correct for radioactive decay and to convert the observed mycelial radioactivity to equivalents of potassium where necessary. The counting error was less than $\mathrm{I} \%$.

Total potassium in mycelia was estimated by flame emission spectrophotometry using a Unicam SP9oA absorption/emission flame spectrophometer, after digesting the sample with conc. $\mathrm{HNO}_{3}$.

Demineralized water used throughout had a specific resistance in excess of $1 \cdot 0 \mathrm{M} \Omega / \mathrm{cm}^{3}$. Valinomycin was purchased from Sigma, 2,4-dinitrophenol from I.C.N.-K \& K Laboratories, Plainview, New York, U.S.A., and sodium azide from BDH. All other chemicals used were analytical grade.

\section{RESULTS}

\section{Time relationships and kinetics}

Despite the high $\mathrm{K}^{+}$content of mycelium grown in Medium GI (Budd, 1969b), a small net uptake of $\mathrm{K}^{+}$occurred when the mycelium was transferred to dilute $\mathrm{KCl}$ solutions. This uptake was too small in relation to initial $\mathrm{K}^{+}$content for accurate determinations of net $\mathrm{K}^{+}$influx to be made. Preliminary experiments suggested that this net uptake was at least partly a response to the osmotic swelling which occurred when the mycelium was transferred from the growth medium (approx. $0.3 \mathrm{osm}$ at harvest) to these more dilute solutions. Initially, attempts were made to measure the 'steady-state' $\mathrm{K}^{+}$influx in mycelia pre-equilibrated in non-radioactive $\mathrm{KCl}$ solutions of various concentrations for 2 to $3 \mathrm{~h}$. 


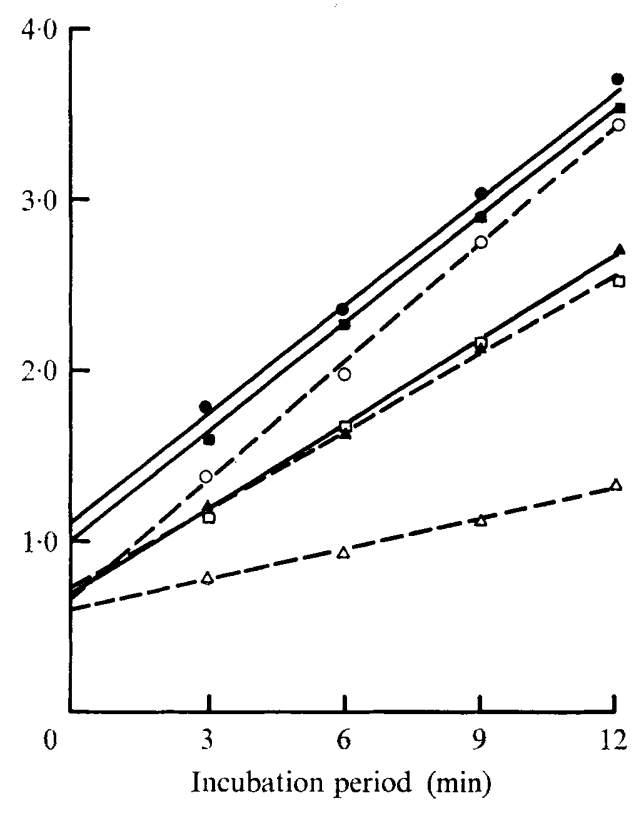

Fig. I

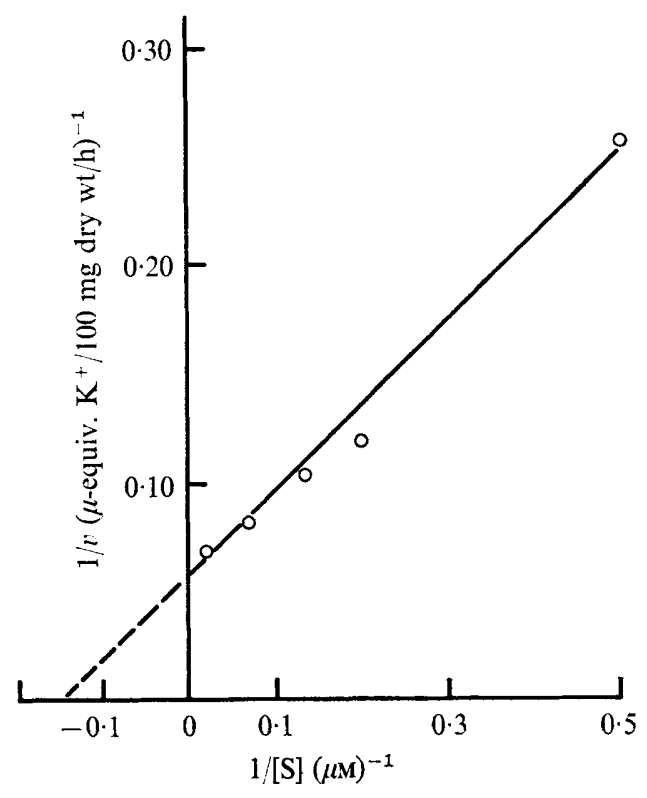

Fig. 2

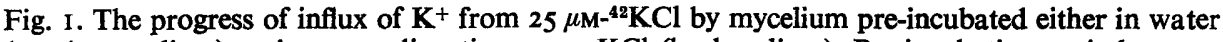
(continuous lines) or in non-radioactive $25 \mu \mathrm{M}-\mathrm{KCl}$ (broken lines). Pre-incubation periods were: $O, 2 \mathrm{~min} ; 0,22 \mathrm{~min} ; \square, 64 \mathrm{~min} ; \square, 86 \mathrm{~min} ; \triangle, 150 \mathrm{~min}, \Delta, 162 \mathrm{~min}$. Temperature, $23{ }^{\circ} \mathrm{C}$.

Fig. 2. Double reciprocal plot for rates of $\mathrm{K}^{+}$influx for the concentration range $2 \cdot 0$ to $50 \cdot 0 \mu \mathrm{M}-\mathrm{KCl}$. Temperature, $23^{\circ} \mathrm{C}$.

The influxes measured in this way were not reproducible and were very low compared with the maximum $\mathrm{K}^{+} / \mathrm{Na}^{+}$exchanges rates already observed (Budd, 1969b). Rather than extend the pre-equilibration period, the $\mathrm{K}^{+}$influx rates of mycelium freshly harvested and washed were examined as a function of time of pre-incubation in demineralized water. Under these conditions, $\mathrm{K}^{+}$influxes proved to be quite reproducible (Fig. I), at least for the first 80 to $90 \mathrm{~min}$ incubation in demineralized water. In contrast, mycelium pre-incubated in $25 \mu \mathrm{M}-\mathrm{KCl}$ solution showed a progressive decline in influx rate with increased time of pre-incubation. However, influx appeared always to be linear with time for approximately 12 min following an initial rapid adjustment (adsorption, see below). Every estimate of influx rate represents the slope of an influx time-course based on at least four consecutive determinations of radioactivity taken within an 8 to $12 \mathrm{~min}$ exposure to ${ }^{42} \mathrm{~K}^{+}$. The contribution of adsorption is thus not included in influx determinations, and is discussed separately below.

The kinetics of $\mathrm{K}^{+}$influx were examined using mycelium held in water for a maximum of $\mathrm{I} h$ before exposure to ${ }^{42} \mathrm{~K}^{+}$. Figure 2 shows the results for the range 2 to $50 \mu \mathrm{M}-\mathrm{KCl}$. These indicate a single kinetic system mediating $\mathrm{K}^{+}$influx in this concentration range, with an apparent $K_{m}$ (data of Fig. 2) of $6.7 \mu$-equiv. $\mathrm{K}^{+} / 1$ and a $V_{\max }$ of approximately I8.o $\mu$-equiv. $\mathrm{K}^{+} / 100 \mathrm{mg}$ dry wt/h (average values from three estimates; $K_{m} 6 \cdot 3 \mu$-equiv. $\mathrm{K}^{+} / 1, V_{\max } 17 \cdot 4 \mu$-equiv. $\mathrm{K}^{+} / 100 \mathrm{mg}$ dry $\mathrm{wt} / \mathrm{h}$ ). Neocosmospora thus possesses a $\mathrm{K}^{+}$ transport system of relatively high affinity for $\mathrm{K}^{+}$.

The specificity of this transport system also appeared to be high. In the presence of 

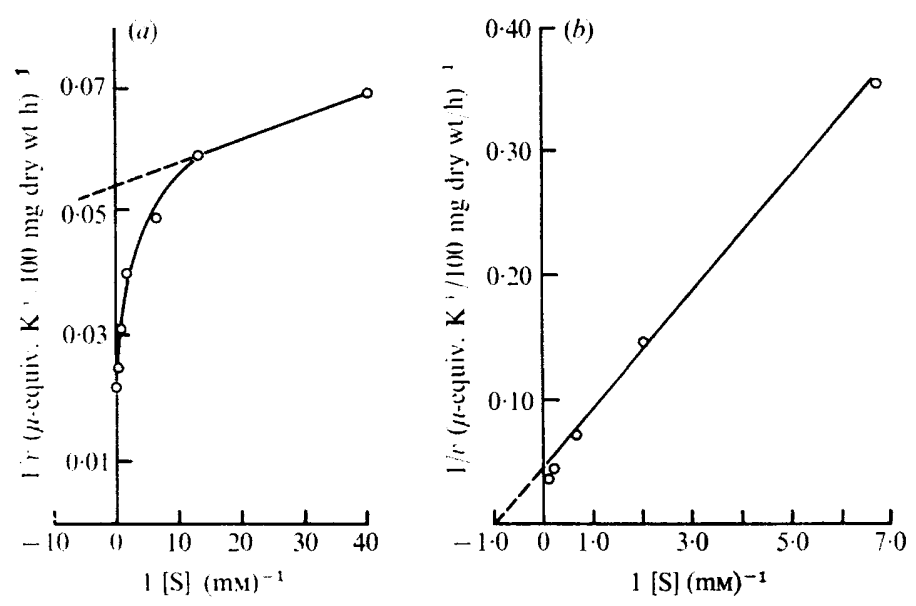

Fig. 3. Double reciprocal plots for rates of $\mathrm{K}^{+}$influx at $24{ }^{\circ} \mathrm{C}$ for the concentration ranges $(a)$ 0.025 to $15.0 \mathrm{~mm}-\mathrm{KCl}$, and $(b) 0.15$ to $15.0 \mathrm{mM}-\mathrm{KCl}$. The data for $(b)$ are those for $(a)$ corrected for the contribution of the high-affinity $\mathbf{K}^{+}$influx system (see text).

either $\mathrm{Na}^{+}$or $\mathrm{Mg}^{++}$at $2.5 \mathrm{~m}$-equiv./1, $\mathrm{K}^{+}$influx from $25 \mu \mathrm{M}-\mathrm{KCl}$ was depressed by only approximately $40 \%$.

Influx kinetics in the range $25 \mu \mathrm{M}-$ to $15 \mathrm{mM}-\mathrm{KCl}$ are presented in Fig. $3(a)$ and $(b)$. The double reciprocal plot in Fig. 3(a) is strongly curved, indicating the participation of more than a single system for $\mathrm{K}^{+}$influx over this concentration range. Extrapolation of the tangent to the upper arm of this curve gives an intercept on the abscissa corresponding to a $K_{m}$ of $7.0 \mu \mathrm{M}$, and its ordinate intercept yields a value for $V_{\max }$ of $18.5 \mu$-equiv. $\mathrm{K}^{+} / 100 \mathrm{mg}$ dry $w t / h$. Both values clearly refer to the high-affinity system already discussed. All other influx values in Fig. 3(a) must be corrected for influx via this system, and it appears that the kinetic characteristics of the influx system are sufficiently distinct for this to be a simple operation. Using the Briggs-Haldane equation:

$$
v_{1}=\frac{V_{\max }[\mathrm{S}]}{K_{m}+[\mathbf{S}]},
$$

where $v_{1}$ indicates influx via the high-affinity system only, [S] the $\mathrm{KCl}$ concentration in $\mathrm{mM}$, and $V_{\max }$ and $K_{m}$ have the values given above, $v_{1}$ is calculated for all $\mathrm{KCl}$ concentrations in Fig. 3(a) and subtracted from the observed influx. The resulting values are replotted in Fig. $3(b)$, and form a moderately good fit to the line shown. The values of $K_{m}$ and $V_{\max }$ given by this line are, respectively, I.0 $\mathrm{mM}$ and $2 \mathrm{I} \cdot 7 \mu$-equiv. $\mathrm{K}^{+} / 100 \mathrm{mg} \mathrm{dry} \mathrm{wt} / \mathrm{h}$. Neocosmospora thus appears to possess both a low- and a high-affinity system for $\mathrm{K}^{+}$ influx.

The properties of this low-affinity system have not been extensively examined because of the technical difficulty of separating it from the high-affinity system in normal mycelium. Further experiments were confined to examining this latter system, except as noted below.

\section{Metabolic aspects of $K^{+}$influx}

Table I shows the effects of several metabolic inhibitors and anaerobiosis on $\mathrm{K}^{+}$influx. Dinitrophenol and sodium azide were added to the mycelial suspension immediately before the ${ }^{42} \mathrm{KCl}$ : the dinitrophenol was at a concentration known to uncouple respiration 


\section{Table $\mathrm{I}$. The effects of metabolic inhibition on $K^{+}$influx and adsorption}

Influx was measured over $12 \mathrm{~min}$ after addition of ${ }^{42} \mathrm{KCl}$. Adsorption was determined as the ordinate (zero-time) intercept extrapolated from each influx time-course. 2,4-Dinitrophenol was adjusted to $\mathrm{pH} 5.6$ with $\mathrm{NaOH}$, and sodium azide and sodium arsenate to pH 5.8 with $\mathrm{H}_{2} \mathrm{SO}_{4}$. The $\mathrm{pH}$ of control suspensions was 5.4 to 5.5 .

\begin{tabular}{|c|c|c|c|}
\hline Expt no. & Treatment & $\begin{array}{l}\left(\mu \text {-equiv. } \mathrm{K}^{+} /\right. \\
\text {I00 mg dry wt/h) }\end{array}$ & $\begin{array}{l}\left(\mu \text {-equiv. } \mathrm{K}^{+} /\right. \\
100 \mathrm{mg} \text { dry wt) }\end{array}$ \\
\hline I & $\begin{array}{l}\text { Control ( } 25 \mu \mathrm{M}-\mathrm{KCl} \text { only) } \\
10^{-4} \mathrm{M}-2,4-d i n i t r o p h e n o l \\
0.09 \mathrm{mM}-\mathrm{NaCl}^{*} \\
10^{-8} \mathrm{M} \text {-sodium azide } \\
10^{-3} \mathrm{M} \text {-sodium chloride } \dagger\end{array}$ & $\begin{array}{r}\text { II } \cdot 68 \\
0.20 \\
10.96 \\
0.04 \\
8 \cdot 00\end{array}$ & $\begin{array}{l}0.88 \\
0.25 \\
0.94 \\
0.20 \\
0.55\end{array}$ \\
\hline 2 & $\begin{array}{l}\text { Control }(25 \mu \mathrm{M}-\mathrm{KCl}) \\
\text { Anaerobic }\end{array}$ & $\begin{array}{r}\text { II } 50 \\
0.15\end{array}$ & $\begin{array}{l}0.80 \\
0.93\end{array}$ \\
\hline 3 & $\begin{array}{l}\text { Control }(25 \mu \mathrm{M}-\mathrm{KCl}) \\
\text { Sodium arsenate }(1 \cdot 0 \mathrm{mM}) \\
\text { Sodium chloride }(2 \cdot 0 \mathrm{mM}) \ddagger\end{array}$ & $\begin{array}{r}16 \cdot 70 \\
0.40 \\
10 \cdot 40\end{array}$ & $\begin{array}{l}0.50 \\
0.45 \\
0.45\end{array}$ \\
\hline 4 & $\begin{array}{l}\text { Control ( } 5 \mathrm{mM}-\mathrm{KCl}) \\
10^{-4} \mathrm{M}-2,4 \text {-dinitrophenol } \\
\text { Anaerobic }\end{array}$ & $\begin{array}{r}44.80 \\
4.40 \\
0.80\end{array}$ & $\begin{array}{l}12.00 \\
11 \cdot 55 \\
12 \cdot 55\end{array}$ \\
\hline
\end{tabular}

in Neocosmospora (Miller \& Budd, 1975). Both of these inhibitors gave very marked ( 90 to $99 \%$ ) inhibition of $\mathrm{K}^{+}$influx within 3 min. Anaerobiosis was attained by suspending the mycelium in deoxygenated water and bubbling with $\mathrm{N}_{2}$ gas for $5 \mathrm{~min}$ before the addition of ${ }^{42} \mathrm{KCl}$. At both $25 \mu \mathrm{M}$ - and $5 \mathrm{mM}-\mathrm{KCl}$, anaerobiosis gave over $98 \%$ inhibition of $\mathrm{K}^{+}$influx. The short deprivation of oxygen in these experiments would not lead to irreversible physiological effects (Miller \& Budd, 1975). Arsenate (experiment 3) was tested both with and without a 5 min pre-incubation before adding ${ }^{42} \mathrm{KCl}$, but only the results for mycelium pre-incubated in the inhibitor are presented. Influx was unaffected by arsenate at this concentration for 4 to $6 \mathrm{~min}$, after which there was essentially complete inhibition.

Table I also shows the effects of metabolic inhibition on $\mathrm{K}^{+}$adsorption (determined by the graphical method, see below). As expected, neither anaerobiosis nor sodium arsenate reduced adsorption when compared with the appropriate control. At $25 \mu \mathrm{M}-\mathrm{KCl}$, however, both dinitrophenol and sodium azide strongly depressed adsorption. At $5.0 \mathrm{mM}-\mathrm{KCl}$, dinitrophenol scarcely affected adsorption.

Glucose ( $1.0 \mathrm{mM}$ ) slightly stimulated influx from $25 \mu \mathrm{M}-\mathrm{KCl}$ (up to $30 \%$ ); its effect at $5^{\circ} \circ \mathrm{mm}-\mathrm{KCl}$ was not tested. Net potassium uptake was not increased by glucose (see also Budd, $1969 b$ ).

Valinomycin at $\mathrm{I} \cdot 0$ to $4.0 \mu \mathrm{g} / \mathrm{ml}$ had no measurable influence on influx from $25 \mu \mathrm{M}$ ${ }^{42} \mathrm{KCl}$.

\section{Efflux of $K^{+}$}

Potassium efflux was examined after only short periods ( $\mathrm{I} \cdot 0$ or $2.5 \mathrm{~h}$ ) of loading with ${ }^{42} \mathrm{~K}^{+}$: no attempt was made to grow Neocosmospora in the presence of the isotope. Figure 4 shows efflux into $25 \mu \mathrm{M}-\mathrm{KCl}$ following I or $2.5 \mathrm{~h}$ preloading with ${ }^{42} \mathrm{~K}^{+}$from $25 \mu \mathrm{M}-\mathrm{KCl}$. Following an initial adjustment (desorption?) which appeared to be complete 


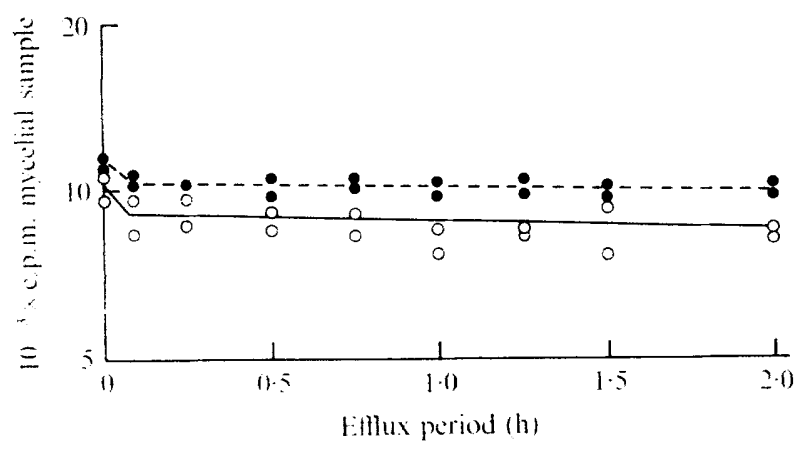

Fig. 4

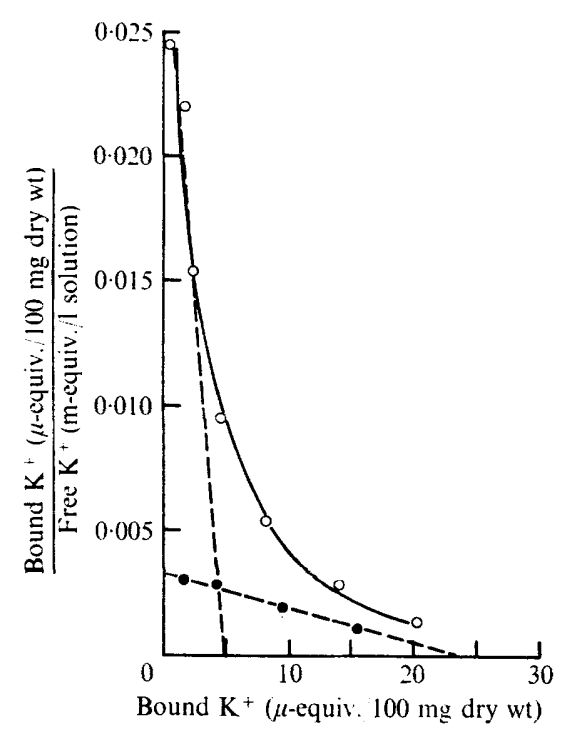

Fig. 5

Fig. 4. The efflux of ${ }^{42} \mathrm{~K}^{+}$to $25 \mu \mathrm{M}$ non-radioactive $\mathrm{KCl}$. Mycelium was preloaded in $25 \mu_{\mathrm{M}}{ }^{42} \mathrm{KCl}$ for $(O)$ i h or $0,2.5 \mathrm{~h}$. Temperature, $24{ }^{\circ} \mathrm{C}$. The results of two parallel experiments are shown.

Fig. 5. Scatchard plot of the data for $\mathrm{K}^{+}$adsorption for the concentration range 0.025 to $15.0 \mathrm{~mm}-\mathrm{KCl}$. $\bigcirc$, Original data; $O$, replotted 'data (see text). All curves fitted by inspection. Temperature, $24^{\circ} \mathrm{C}$.

within 5 min (the shortest efflux period measured), efflux of ${ }^{42} \mathrm{~K}^{+}$was extremely slow. The exact pattern of efflux could not be discerned from these data, because the sampling error was appreciable compared with the actual loss. For simplicity, however, the post-desorption efflux in Fig. 4 is represented as taking place from a single kinetic compartment. On the assumption that all mycelial $\mathrm{K}^{+}$(other than that adsorbed to the mycelial surface) was located within this compartment, a maximum value for $\mathrm{K}^{+}$efflux was calculated by multiplying the percentage loss per hour from the compartment, by the total $\mathrm{K}^{+}$within it. Table 2 presents estimates of efflux made in this way, with measurements of influx from parallel experiments where these were available. Whereas influx decreased markedly after I50 min in $25 \mu \mathrm{M}-\mathrm{KCl}$ as compared with $60 \mathrm{~min}$, efflux to $25 \mu \mathrm{M}-\mathrm{KCl}$ was not significantly changed. The estimated half-times for ${ }^{42} \mathrm{~K}^{+}$loss from the mycelium were $20.3 \mathrm{~h}$ for $60 \mathrm{~min}$ preloading, and $18.2 \mathrm{~h}$ for $150 \mathrm{~min}$. Influx considerably exceeded efflux after $60 \mathrm{~min}$ in $25 \mu \mathrm{M}-\mathrm{KCl}$, but was about equal to it after I $50 \mathrm{~min}$. These results show that the mycelium was close to equilibrium with $25 \mu$-equiv. $\mathrm{K}^{+} / 1$ after $150 \mathrm{~min}$, and indicate that equilibrium was approached primarily by regulation of $\mathrm{K}^{+}$influx.

The data concerning $5 \mathrm{~mm}$-external $\mathrm{KCl}$ (at which concentration both influx systems are operating) are less extensive but basically confirm those above. Efflux was about three times as fast to $5 \mathrm{mM}-\mathrm{KCl}$ as to $25 \mu \mathrm{M}$ (Table 2) and the exchange half-time was approximately $6.7 \mathrm{~h}$. Influx rate was close to that of efflux after $\mathrm{I} \mathrm{h}$ in $5 \mathrm{mM}-\mathrm{KCl}$, and was about $7.0 \mu$-equiv./100 mg dry wt/h. This, however, was far below the initial influx rate observed in $5 \mathrm{~mm}-\mathrm{KCl}$, which was approximately $45 \mu$-equiv./100 $\mathrm{mg}$ dry wt/h (Table $\mathrm{I}$ ). Hence, equilibrium was again attained mainly by reduction of influx.

Under anaerobiosis, or with $1^{-4} \mathrm{M}$-dinitrophenol, efflux rate was approximately doubled (Table 2). The half-times for ${ }^{42} \mathrm{~K}^{+}$loss under these conditions were therefore decreased 


\section{Table 2. Efflux and influx of $K^{+}$under various conditions}

Mycelium was preloaded for the times shown, using ${ }^{42} \mathrm{KCl}$ for efflux studies and non-radioactive $\mathrm{KCl}$ for influx. It was then transferred to $\mathrm{KCl}$ of the same concentration for flux measurement (non-radioactive for efflux studies, ${ }^{12} \mathrm{~K}^{+}$-labelled for influx). The average values of $\alpha$ (the specific loss factor) for radioactive $\mathrm{K}^{+}$were as follows: to $25 \mu \mathrm{M}-\mathrm{KCl}, 0.034 / \mathrm{h}$ for $60 \mathrm{~min}$ preloading and $0.038 / \mathrm{h}$ for $150 \mathrm{~min}$ preloading; to $5 \mathrm{mM}-\mathrm{KCl}, 0.103$ (60 min preloading only).

\begin{tabular}{|c|c|c|c|c|c|c|c|c|}
\hline \multirow[b]{2}{*}{ Efflux conditions } & \multirow{2}{*}{$\begin{array}{c}\mathbf{K C l} \\
\text { concn. } \\
\text { during } \\
\text { preloading }\end{array}$} & \multirow{2}{*}{$\begin{array}{c}\text { Pre- } \\
\text { loading } \\
\text { period } \\
\text { (min) }\end{array}$} & \multicolumn{3}{|c|}{$\begin{array}{l}\text { Efflux ( } \mu \text {-equiv. } \mathrm{K}^{+} / \\
\text {I00 mg dry wt } / \mathrm{h})\end{array}$} & \multicolumn{3}{|c|}{$\begin{array}{l}\text { Influx ( } \mu \text {-equiv. } \mathrm{K}+1 \\
\text { 100 mg dry wt } / \mathrm{h} \text { ) }\end{array}$} \\
\hline & & & Mean & S.E.M. & $N$ & Mean & S.E.M. & $N$ \\
\hline $25 \mu \mathrm{M}-\mathrm{KCl}$ & $25 \mu \mathrm{M}$ & 60 & $2 \cdot 41$ & 0.39 & 12 & $9 \cdot 45$ & $0 . I I$ & 4 \\
\hline $25 \mu \mathrm{M}-\mathrm{KCl}$ & $25 \mu \mathrm{M}$ & 150 & 2.47 & 0.78 & 6 & 3.00 & 0.25 & 4 \\
\hline $25 \mu \mathrm{M}-\mathrm{KCl}+0.1 \mathrm{mM}-\mathrm{DNP}$ & $25 \mu \mathrm{M}$ & 60 & 5.07 & - & 2 & - & - & - \\
\hline $25 \mu_{\mathrm{M}-\mathrm{KCl}}$, anaerobic & $25 \mu_{\mathrm{M}}$ & 60 & 4.93 & 一 & 2 & - & 一 & 一 \\
\hline $5 \mathrm{mM}-\mathrm{KCl}$ & $5 \mathrm{~mm}$ & 60 & $7 \cdot 74$ & - & 2 & $7 \cdot 0^{*}$ & $\longrightarrow$ & - \\
\hline
\end{tabular}

but still were of the order of 8 to $10 \mathrm{~h}$, even though the energy supply to the influx systems was presumably almost abolished (see Table I). These results indicate that potassium was not retained within the mycelium primarily by mechanisms dependent on the expenditure of respiratory energy. The mycelial surface membrane was evidently only slightly permeable to $\mathrm{K}^{+}$ions in the outward direction.

Valinomycin, at $4 \mu \mathrm{g} / \mathrm{ml}$, did not increase ${ }^{42} \mathrm{~K}^{+}$efflux to $25 \mu \mathrm{M}-\mathrm{KCl}$ during a $2 \mathrm{~h}$ exposure. The efflux of ${ }^{42} \mathrm{~K}^{+}$to water only was reduced as compared with $\mathrm{KCl}$ solutions (specific loss factor, $\alpha=0.005$ to $0.019 / \mathrm{h}$ ).

\section{Adsorption of $\mathrm{K}^{+}$}

The influx time-courses, though linear with time after the earliest sampling, did not extrapolate to pass through the origin at zero time (cf. Fig. I). Extrapolation gave a positive intercept on the uptake axis, and this was taken to represent $\mathrm{K}^{+}$adsorption. Adsorbed ${ }^{42} \mathrm{~K}^{+}$was not completely removed by brief desorption into non-radioactive $\mathrm{KCl}$. Resuspension of the mycelium for up to $30 \mathrm{~s}$ in $10 \mathrm{mM}-\mathrm{KCl}$ removed $95 \%$ of the ${ }^{42} \mathrm{~K}^{+}$adsorbed from $5 \mathrm{mM}^{-42} \mathrm{~K}^{+}$, but only approximately $65 \%$ of that adsorbed from $50 \mu \mathrm{M}-{ }^{42} \mathrm{KCl}$. Potassium adsorption was thus a heterogeneous phenomenon.

Adsorption of $\mathrm{K}^{+}$was appreciable even in the micromolar concentration range. Figure 5 shows the relationship between $\mathrm{K}^{+}$adsorbed and external $\mathrm{K}^{+}$concentration, plotted according to the method of Scatchard (1949). The curve drawn is the graphical representation of the equation

$$
\bar{v} / c=K(n-\bar{v})
$$

where $\vec{v}$ is the average value of $\mathrm{K}^{+}$adsorbed per unit dry weight ('bound' $\mathrm{K}^{+}$), $c$ is the concentration of $\mathrm{K}^{+}$ions in external solution ('free' $\mathrm{K}^{+}$), $n$ the maximum possible $\mathrm{K}^{+}$ bound, and $K$ the association constant. When $\bar{v} / c$ is plotted against $\bar{v}$, a straight line results if $K$ is constant over the concentration range employed. The intercept on the $\bar{v} / c$ axis is equal to $K n$, and that on the $\bar{v}$ axis equals $n$.

The $\mathrm{KCl}$ concentrations used in this experiment ranged from $25 \mu \mathrm{M}$ to $15 \mathrm{mM}$, and it is clear that the data did not fit a single straight line. The curvature of the line suggested that more than one chemical species (or 'site') at the mycelial surface was responsible for the adsorption of $\mathrm{K}^{+}$. Using this approach (see Scatchard, Coleman \& Shen, 1957), it was possible to resolve the curve of Fig. 5 into two approximations to straight lines. 
Table 3. Characteristics of adsorption sites for $\mathrm{K}^{+}$

\begin{tabular}{|c|c|c|c|}
\hline \multirow[b]{2}{*}{ Site } & \multicolumn{3}{|c|}{$\begin{array}{l}\text { Association constant, } K \\
(1 / \mathrm{mol})\end{array}$} \\
\hline & Mean & S.E.M. & $N$ \\
\hline I & $9.67 \times 10^{3}$ & $2.24 \times 10^{3}$ & 3 \\
\hline 2 & $2.25 \times 10^{2}$ & $0.44 \times 10^{2}$ & 4 \\
\hline
\end{tabular}

\begin{tabular}{|c|c|c|c|c|}
\hline \multirow{2}{*}{$\begin{array}{l}\text { Affinity, I } / K^{*} \\
(\mathrm{~mol} / \mathrm{l})\end{array}$} & \multicolumn{3}{|c|}{$\begin{array}{c}\text { Abundance, } n \\
(\mu \text {-equiv./100 mg dry wt) }\end{array}$} & \multirow{2}{*}{$\begin{array}{c}\text { Relative } \\
\text { abundance } \\
(\%)\end{array}$} \\
\hline & Mean & S.E.M. & $N$ & \\
\hline $\begin{array}{r}1.03 \times 10^{-4} \\
4.4 \times 10^{-3}\end{array}$ & $\begin{array}{r}3 \cdot 6 \\
17 \cdot 7\end{array}$ & $\begin{array}{l}0.7 \\
3.8\end{array}$ & $\begin{array}{l}3 \\
4\end{array}$ & $\begin{array}{l}16 \cdot 0 \\
84.0\end{array}$ \\
\hline
\end{tabular}

* $\mathbf{K}^{+}$concentration for half-saturation.

Assuming that the binding of $\mathrm{K}^{+}$at the lowest concentrations of $\mathrm{KCl}$ described the contribution of a single binding species, the asymptotic tangent was drawn to this (lefthand) arm of the curve (see Fig. 5). From the intercepts of this tangent on the axes, the values of $K_{1}$ and $n_{1}$ (subscripts designate 'site I') were obtained as already described. Values from Fig. 5 were: $K_{1}=6.5 \times 10^{3} 1 / \mathrm{mol} ; n_{1}=4.8 \mu$-equiv. $\mathrm{K}^{+} / 100 \mathrm{mg}$ dry wt.

The tangent itself was then used to correct all other experimental points for the contribution $\left(\bar{v}_{1}\right)$ of site I at all other concentrations of $\mathrm{KCl}$. Values of $\left(\bar{v}-\bar{v}_{1}\right) / c$ were then replotted against $\left(\bar{v}-\bar{v}_{1}\right)$, and the resulting points in Fig. 5 fitted a single straight line. Values of $K_{2}$ and $n_{2}$ obtained from this line were: $K_{2}=\mathrm{I} \cdot 4 \times \mathrm{I}^{2} \mathrm{l} / \mathrm{mol} ; n_{2}=23.3 \mu$ equiv. $\mathrm{K}^{+} / 100 \mathrm{mg}$ dry wt. Hence, only two binding species for $\mathrm{K}^{+}$need be postulated for the concentration range described. Table 3 summarizes available experimental data on these binding species for Neocosmospora. Site I was half-saturated at $0 \cdot \mathrm{I} \mathrm{mM}-\mathrm{KCl}$ and accounted for about one $\mathrm{K}^{+}$ion-binding site in six. Site 2 was half-saturated at approximately $4.4 \mathrm{~mm}-\mathrm{KCl}$ and accounted for the remaining $\mathrm{K}^{+}$-binding sites.

Data already presented indicated that the two binding sites differ in reversibility of $\mathrm{K}^{+}$binding and in their response to certain inhibitors. The anomalous results obtained with desorption into unlabelled $\mathrm{KCl}$ (see above) suggested that adsorption of $\mathrm{K}^{+}$to site 2 (which predominates at $5 \mathrm{mM}-\mathrm{KCl}$ ) was easily and completely reversible, whereas adsorption to site $\mathrm{I}$ (which predominates at $25 \mu \mathrm{M}-\mathrm{KCl}$ ) was not. Similarly, the contrasting effects of dinitrophenol on adsorption at $5 \mathrm{mM}-$ and at $25 \mu \mathrm{M}-\mathrm{KCl}$ (Table I) indicated that only site I was sensitive to this inhibitor.

\section{DISCUSSION}

A striking feature of the above results was the low magnitude of the potassium fluxes compared with the maximum values in the literature for other fungi. In both Neurospora and baker's yeast, a single $\mathrm{K}^{+}$influx system has been reported, with an apparent $K_{m}$ for potassium in the millimolar concentration range and $V_{\max }$ in the region of $20 \mathrm{~m}$-equiv $\mathrm{K}^{+} / 1$ cell-water/min (Slayman \& Tatum, 1965; Armstrong \& Rothstein, 1965). The fluxes expressed in this paper as $\mu$-equiv. $\mathrm{K}^{+} / 100 \mathrm{mg}$ dry $\mathrm{wt} / \mathrm{h}$ can be converted to the above units by dividing by $\mathrm{I} 8$ (in Neocosmospora, $100 \mathrm{mg}$ dry matter is equivalent to $0.30 \mathrm{ml}$ cell-water; Miller \& Budd, 1975). Hence $V_{\max }$ for either the high- or the low-affinity $\mathrm{K}^{+}$ influx system in Neocosmospora was approximately $1 \mathrm{~m}$-equiv. $\mathrm{K}^{+} / 1$ cell-water $/ \mathrm{min}$, or roughly $5 \%$ of the values for Neurospora or yeast. However, because Neocosmospora differs from these other species in also possessing a high-affinity transport-system for $\mathrm{K}^{+}$, potassium influx from $\mathrm{K}^{+}$concentrations below $50 \mu$-equiv. $/ 1$ should be more rapid in Neocosmospora than in these other fungi. Despite these differences, $\mathrm{K}^{+}$influx was closely linked to metabolism in all three fungi.

Potassium efflux was much less rapid in Neocosmospora than in Neurospora. The half-time for $\mathrm{K}^{+}$exchange in Neurospora mycelium in equilibrium with $5 \mathrm{mM}-\mathrm{KCl}$ was 
of the order of 6 to 7 min (Slayman \& Tatum, 1965). In Neocosmospora, it was approximately 6 to $7 \mathrm{~h}$. $\mathrm{K}^{+}$efflux in Neurospora appeared to be strictly an exchange flux, but in Neocosmospora the evidence on this point was inconclusive. Efflux clearly increased as the external $\mathrm{K}^{+}$concentration (and rate of influx) increased, as would be expected of an exchange flux: however, anaerobiosis or dinitrophenol, which essentially eliminate influx, actually caused efflux to increase. Under these conditions, a strict exchange flux should be abolished. It is possible that $\mathrm{K}^{+}$effux in Neocosmospora represented a slow diffusion leak, reduced still further by recapture. Potassium efflux in baker's yeast, which appeared to be a diffusive leak, was of the same order as in Neocosmospora $\left(0.5\right.$ m-equiv. $\mathrm{K}^{+} / 1$ cell-water/min or less; Rothstein \& Bruce, 1958).

The low $\mathrm{K}^{+}$fluxes observed in Neocosmospora appeared to reflect both a low passive permeability of the mycelial surface membrane to $\mathrm{K}^{+}$, and strict metabolic control over the energy-dependent influx processes. The approach to equilibrium with external $\mathrm{K}^{+}$ solutions (and hence the regulation of mycelial $\mathrm{K}^{+}$content) appeared to involve a decrease in $\mathrm{K}^{+}$influx, rather than an increase in $\mathrm{K}^{+}$efflux. One advantage of such a method of regulation would be the conservation of respiratory resources. In baker's yeast, equilibration with external $\mathrm{K}^{+}$solutions involved a time-dependent increase in $\mathrm{K}^{+}$efflux, though at external $\mathrm{K}^{+}$concentrations above $\mathrm{I}$ m-equiv. $\mathrm{K}^{+} / 1$ there was evidence that influx was reduced after prolonged uptake (Rothstein \& Bruce, 1958). Whether Neurospora is similar is not clear; however, the exchange fluxes of $\mathrm{K}^{+}$at equilibrium were much greater than in Neocosmospora (see above).

The internal signals responsible for regulating $\mathrm{K}^{+}$influx in Neocosmospora have not been identified. It is probable that cytoplasmic $\mathrm{K}^{+}$concentration is one regulatory factor, but if net $\mathrm{K}^{+}$uptake involves exchange for $\mathrm{H}^{+}$ions (Budd, $\mathrm{I} 969 \mathrm{~b}$ ) then cytoplasmic $\mathrm{pH}$ might be another. Uptake of $\mathrm{K}^{+}$in exchange for $\mathrm{Na}^{+}$in low-potassium mycelium of Neocosmospora (Budd, 1969b) was up to fourfold faster than the maximum $\mathrm{K}^{+}$influx from the same $\mathrm{KCl}$ concentration with normal mycelium, as observed in the present work. This suggests that mycelial $\mathrm{K}^{+}$content did influence $\mathrm{K}^{+}$influx rate, but since the low- $\mathrm{K}^{+}$mycelium was grown on limited $\mathrm{K}^{+}$, further work will be necessary to separate direct (inhibitory) effects of mycelial $\mathrm{K}^{+}$from possible indirect (repressive) effects on influx.

The data on adsorption in this paper are essentially preliminary, and no information is available concerning the chemical nature or cytological location of the adsorption sites. Adsorption is commonly observed during cation uptake in fungi (Rothstein \& Hayes, 1956; Budd \& Harley, 1962; Ponta \& Broda, 1970; Shere \& Jacobson, 1970; Paton \& Budd, 1972), as in other organisms, but it is less conspicuous with the monovalent cations than with di- or polyvalent ones. Adsorption of $\mathrm{K}^{+}$was observed in yeast (Rothstein \& Hayes, 1956), where it displaced $\mathrm{Mn}^{2+}$ from one of the two binding sites for this ion. The association constant calculated from their data is approximately $2 \times 10^{2} \mathrm{l} / \mathrm{mol}$, or very close to that for site 2 in Neocosmospora. However, the total surface binding of cations by yeast was no more than $3 \mathrm{mmol} / \mathrm{kg}$ cells (Rothstein \& Hayes, 1956) whereas in Neocosmospora this figure is at least $50 \mathrm{mmol} / \mathrm{kg}$ cells. With Neurospora, potassium adsorption was not appreciable below pH 5.8 (Slayman \& Slayman, 1970), and at $\mathrm{pH} 8$ reached a maximum value of approximately $25 \mu$-equiv./100 $\mathrm{mg}$ dry wt, similar to that observed for Neocosmospora at $\mathrm{pH}$ values between 5.5 and $6 \cdot 0$. The association constant for $\mathrm{K}^{+}$, however, was very low $(3 \mathrm{I} \mathrm{l} / \mathrm{mol})$, and only a single adsorption site was discernible. Evidently, these three fungi differ considerably in their surface properties, as well as in the characteristics of their $\mathrm{K}^{+}$fluxes. 
This work was supported by grants Nos. A28I3 and E253I from the National Research Council of Canada.

\section{REFERENCES}

Armstrong, W. M. \& Rothstein, A. (1965). Discrimination between alkali metal cations by yeast. I. Effect of $\mathrm{pH}$ on uptake. Journal of General Physiology 48, 6I-71.

BuDD, K. (1969a). The assimilation of bicarbonate by Neocosmospora vasinfecta. Canadian Journal of Microbiology 15, 389-398.

BuDD, K. (1969b). Potassium transport in non-growing mycelium of Neocosmospora vasinfecta. Journal of General Microbiology 59, 229-238.

BUdD, K. \& HARLeY, J. L. (1962). The uptake and assimilation of ammonia by Neocosmospora vasinfecta. II. Increases in the ammonia level in the mycelium during the uptake of ammonia. New Phytologist 6r, 244-255.

MIlleR, A. G. \& BUDD, K. (1975). Halide uptake by the filamentous ascomycete Neocosmospora vasinfecta. Journal of Bacteriology 121, 9 I-98.

PAton, W. H. N. \& BUDD, K. (1972). Zinc uptake in Neocosmospora vasinfecta. Journal of General Microbiology 72, 173-184.

Ponta, H. \& BrodA, E. (1970). Mechanismen der Aufnahme von Zink durch Bäckerhefe. Planta 95, I8-26.

Rothstein, A. \& BruCE, M. (1958). The potassium efflux and influx in yeast at different potassium concentrations. Journal of Cellular and Comparative Physiology 51, 145-1 59.

Rothstern, A. \& Hayes, A. D. (1956). The relationship of the cell surface to metabolism. XIII. The cation-binding properties of the yeast cell-surface. Archives of Biochemistry and Biophysics 63, 87-99.

Scatchard, G. (1949). The attraction of proteins for small molecules and ions. Annals of the New York Academy of Sciences 51, 660-672.

Scatchard, G., Coleman, J. S. \& Shen, A. L. (1957). Physical chemistry of protein solutions. VII. The binding of some small anions to serum albumin. Journal of the American Chemical Society 79, 12-20.

SHERE, S. M. \& JACOBSON, L. (1970). Mineral uptake in Fusarium oxysporum f. sp. vasinfectum. Physiologia plantarum 23, 5I-62.

Slayman, C. W. \& Slayman, C. L. (1970). Potassium transport in Neurospora. Evidence for a multisite carrier at high pH. Journal of General Physiology 55, 758-786.

Slayman, C. W. \& Tatum, E. L. (1965). Potassium transport in Neurospora. II. Measurement of steadystate potassium fluxes. Biochimica et biophysica acta 102, 149-160. 